\title{
Primer Dismenore ağrısında tamamlayıcı ve alternatif tedavi yöntemleri kullanımı
}

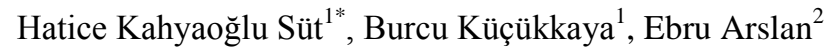 \\ ${ }^{1}$ Trakya Üniversitesi, Sağlık Bilimleri Fakültesi, Hemşirelik Bölümü, Kadın Sağlığı ve Hastalıkları Hemşireliğgi \\ Anabilim Dalı, Edirne, Türkiye \\ ${ }^{2}$ Trakya Üniversitesi, Sağlık Bilimleri Enstitüsü, Hemşirelik Yüksek Lisans Programı, Edirne, Türkiye \\ email: haticesut@yahoo.com, burcukucukkaya1992@gmail.com, ebrum.arslan@gmail.com \\ Orcid: 0000-0001-8840-6846 \\ Orcid: 0000-0002-3421-9794 \\ Orcid: 0000-0002-8670-2083
}

*Sorumlu Yazar / Corresponding Author: Sorumlu Yazar: Hatice Kahyaoğlu Süt

Gönderim Tarihi / Received: 21.05.2019

Kabul Tarihi / Accepted: 26.12.2019

DOI: $10.34087 /$ cbusbed.568502

\begin{abstract}
Amaç: Primer dismenore ağrısında kullanılan tamamlayıcı ve alternatif tedavi yöntemlerinin incelenmesi amaçlanmıştır.

Gereç ve Yöntem: Kesitsel tipte bu araştırma, Aralık 2017-Mayıs 2018 tarihleri arasında... Üniversitesi Kadın Hastalıkları ve Doğum Polikliniği'ne ve Acil Servis İzlem Alanı'na başvuran kadınlar üzerinde yürütülmüştür. 1849 yaş arası 406 kadın çalışmaya dahil edilmiştir. Katılımcılara kişisel ve menstrual siklus bilgileri, primer dismenore semptomları, tamamlayıcı ve alternatif tedavi yöntemleri (TAT) kullanımına ilişkin soruları içeren anket formu uygulanmıştır.

Bulgular: Kadınların yaş ortalaması $26.2 \pm 8.2$ 'dir. Kadınların \%85.5'inin primer dismenore ağrısı yaşadığı, \%58.6'sının ağrı ile baș etmede TAT yöntemlerini kullandığı belirlenmiștir. TAT yöntemlerinin faydalı olduğunu düşünenlerin oranı \%61.1'dir. Kadınlar primer dismenore ağrısını azaltmak ve rahatlamak için sırasıyla; yüzüstü ve cenin pozisyonunda uzanma (\%57.9), sicak duş alma (\%57.6), uyuma (\%57.6), ayaklarına 1sı uygulama $(\% 55.5)$, karına 1sı uygulama (\%52.2), karına masaj yapma (\%50.2), yürüyüş/egzersiz yapma (\%39.9), müzik dinleme (\%38.7), dua etme (\%31.5), nefes egzersizi (\%25.9), akupressure (\%15.8) tamamlayıcı tedavi yöntemlerini uyguladıklarını belirtmișlerdir. Kadınların alternatif (bitkisel/besinsel) tedavi yöntemleri içerisinde en yaygın kullandıkları yöntemler sırasıyla; ıhlamur çayı (\%35.2), yeşil çay $(\% 31)$, papatya çayı (\%30), sıcak süt $(\% 27.3)$, siyah çay (\%22.4), tarçın (\%18.2), rezene çayı (\%14) ve kiraz sapı çayı (\%13.5)'dır.

Sonuç: Genç kadınların büyük çoğunluğu primer dismenore ağrısı yaşamakta ve ağrı ile baş etmek için TAT yöntemlerini sıklıkla kullanmaktadır. Bu nedenle, primer dismenore ağrısı ile baş etmek için kadınlara TAT yöntemleri hakkında kanıta dayalı bilgilendirme yapılması ve bilinçli kullanım farkındalığını kazandırması gerekmektedir.
\end{abstract}

Anahtar Kelimeler: Ağrı, Primer Dismenore, Tamamlayıcı, Alternatif Tedavi.

\footnotetext{
Abstract

Objective: The aim of this study is to investigate the use of complementary and alternative treatment methods for pain in primary dysmenorrhea.

Material and Method: This cross-sectional study was conducted on women who applied to the Obstetrics\&Gynecology and Emergency Departments of the ... University. 406 women whose age of 18-49 were included. A questionnaire including personal ans menstrual cycles, primary dysmenorrhea symptoms and regarding with use of CAT methods was filled by the participants.

Results: The mean age of women was $26.2 \pm 8.2$ years. Of the women, $85.5 \%$ had pain from primary dysmenorrhea, and $58.6 \%$ used CAT methods in coping with pain. $61.1 \%$ of them reported that CAT are beneficial. Women reported that were performed complementary therapies for primary dysmenorrhea pain in the following rates; Lying in a fetal position $(57.9 \%)$, hot shower $(57.6 \%)$, sleep $(57.6 \%)$, heat application to feet $(55.5 \%)$, heat application to abdomen $(52.2 \%)$, do massage to abdomen $(50.2 \%)$, walking\&exercise $(39.9 \%)$, listening to music $(38.7 \%)$, praying $(31.5 \%)$, breathing exercises $(25.9 \%)$, akupressur $(15.8 \%)$.
} 
Linden tea $(35.2 \%)$, green tea $(31 \%)$, chamomile tea $(30 \%)$, hot milk $(27.3 \%)$, black tea $(22.4 \%)$, cinnamon $(18.2 \%)$, fennel tea $(14 \%)$, and cherry stalk tea $(13.5 \%)$ are the most used alternative herbal/nutritional treatment methods among women.

Conclusion: Majority of young women have primary dysmenorrhea pain and they frequently use CAT methods to cope with it. Women should be informed based on evidence about CAT methods in order to cope with primary dysmenorrhea pain, and, an awareness about conscious use of them should be gained to women.

Keywords: Pain, Primary Dysmenorrhea, Complementary, Alternative Therapy.

\section{Giriș}

Uterin menstruel kasılmalar olarak tanımlanan dismenore, üreme çağındaki kadınlarda en sık görülen jinekolojik problemdir. Menstruasyon döneminden önce veya menstruasyon döneminde bazı kadınlar uterin kasılmalar nedeniyle ağrı problemi yaşarlar. İlk ağrılı menstruasyon genellikle menarştan kısa bir süre sonra (6-12 ay) ortaya çıkar [1,2]. Uterin kasılmalar birkaç dakika sürebilir ve $60 \mathrm{~mm}$ Hg'den daha büyük uterus içi basınç artışına yol açabilir [3]. Bu ağrı genellikle menstruasyon başlangıcından bir veya iki gün önce başlar ve menstruasyonun ilk iki günü devam edebilir. Dismenore genellikle genç kadınlarda, özellikle yirmili yaşların başında görülür ve tüm dünyada $\% 70$ 'den fazla genç kadını etkileyen en yaygın jinekolojik şikayetlerden biridir [1,4]. Patolojik bir durumla ilişkili olmayan bir semptom olarak ya da endometrium ve reprodüktif bozuklukların (endometriozis, adenomyozis, fibroidler ve pelvik inflamatuar hastalık) sonucu olarak ortaya çıkarlar [2]. Klinik değerlendirmede, dismenore genellikle primer ve sekonder olarak iki gruba ayrilır [4]. Primer dismenorede, ağrı mensturasyonun ilk ve ikinci günü bazen de üçüncü günü ortaya çıkabilir. Primer dismenore çoğunlukla sakral olarak sırt ağrısı ile birlikte ortaya çıkar ve alt ekstremitelerin üst kısmına yayılabilir. Bunlara bulantı, kusma, diyare ve nadiren senkop semptomları eşlik edebilir [2,5]. Primer dismenore, genç kadınların yaşam kalitesini etkileyerek, kişisel ve sosyal sağlıklarını bozabilmektedir [6].

Günümüz modern ve bilimsel tedavileri dışında uygulanan tedavilerin çoğunluğu genel olarak Tamamlayıcı ve Alternatif Tedavi (TAT) olarak ifade edilmektedir. Primer dismenore ağrısı başladığında, genellikle kadınlar bir doktora ya da sağlık kuruluşuna başvurmak yerine TAT yöntemlerine sıklıkla başvurmaktadırlar [7]. Ülkemizde yapılan bir çalışmada, kadınların farmakolojik yöntemler dışında dismenore ağrısını hafifletmek için sıcak uygulama, egzersiz, masaj, bitkisel tedavi gibi TAT yöntemlerini kullandığı belirtilmiştir [8]. Sağlık profesyonelleri ve hemşireler, TAT yöntemi kullanan ve bu yöntemler hakkında sorular soran kadınlar ile karşılaşabilmektedir. TAT yöntemleri hakkında yetersiz ya da yanlış bilgisi olan kadınların bu yöntemleri bilinçsizce kullanması, yarardan çok zarara yol açabilmektedir. $\mathrm{Bu}$ nedenle, sağlık profesyonelleri ve hemşireler tarafindan kadınlara TAT yöntemlerine ilişkin kanıt düzeyi yüksek bilimsel destekli bilgilendirilme yapılmalı ve bilinçli TAT yöntemleri kullanım farkındalığının kazandırılması sağlanmalıdır. $\mathrm{Bu}$ çalışmada, kadınlarda Primer Dismenore ağrısında kullanılan tamamlayıcı ve alternatif tedavi yöntemlerinin incelenmesi amaçlanmıştır.

\section{Gerec ve Yöntem}

Kesitsel tipte bu araştırma, Aralık 2017-Mayıs 2018 tarihleri arasında, ... Üniversitesi Kadın Hastalıkları ve Doğum Polikliniğine ve Acil Servis İzlem Alanına başvuran 18-49 yaş arası kadınlar üzerinde yürütülmüştür.

Araştırmada, öncelikle TAT yöntemleri kullanım oranının belirlenmesi amaçlanmıştır. Uğurluel ve ark. (2007) yaptığ 1 çalışmada TAT yöntemleri kullanım oranı \%44 olarak baz alınarak, \%0,1 yanılma payı ve $\mathrm{d}=0,088$ tolerans değeri ile $\mathrm{n}=406$ kadının çalışmaya alınması gerektiği hesaplanmıştır [9]. Araştırmanın etik uygunluğu için çalışmanın yürütüldüğü... Üniversitesi Bilimsel Araştırmalar Etik Kurulu'ndan BAEK 2017/345 nolu etik onay, verilerin toplanması için... Üniversitesi Hastanesi Başhekimliği'nden yazılı izin ve çalışmaya katılmayı kabul eden katılımcılardan da bilgilendirilmiş sözlü onam alınmıştır.

Katılımcılara kişisel bilgiler, primer dismenore, TAT yöntemleri ve kullanımına ilişkin soruları içeren anket formu uygulanmıştır. Araştırmacılar tarafından literatür doğrultusunda hazırlanan anket formu; kadınların kişisel özelliklerini içeren 6 soru, menstruasyon ile ilgili özelliklerini içeren 3 soru, Primer Dismenore ile ilgili özelliklerini içeren 7 soru, Primer Dismenore ağrısı ile baş etmede kullanılan tamamlayıcı tedavi yöntemlerini içeren 15 soru, Primer Dismenore Semptomları ağrısı ile baş etmede kullandıkları alternatif tedavi yöntemlerini içeren 25 soru olmak üzere toplam 57 sorudan oluşmaktadır [8, 10-12].

Veriler, ... Üniversite Hastanesinin Kadın Hastalıkları ve Doğum Polikliniği ve Acil Servis İzlem Alanı'nda toplanmıştır. Acil Servis İzlem Alanı'na başvuran kadınların tedavisi bittikten sonra anket uygulanmıştır. Verilerin toplanmasına başlanmadan önce katılımcılara çalışmanın amacı hakkında bilgi verilmiştir. Çalışmaya katılmayı kabul eden katılımcıların anket formunu doldurmaları yaklaşık $10 \mathrm{dk}$ sürmüştür. Verilerin analizinde, SPSS 23,0 paket programı ile tanımlayıcı istatistik yapılmıştır. Sayısal sonuçlar, ortalama \pm standart sapma (Ort \pm SS); kategorik sonuçlar ise sayı (n) ve yüzde (\%) ile gösterilmiştir.

\section{Bulgular}

Çalışmada kadınların yaş ortalamasının 26.2 \pm 8.2 , $\% 70.7$ 'sinin bekar, \%86.2'sinin aile tipi çekirdek, $\% 85$ 'inin lise ve üzeri eğitim durumuna sahip, 
\%77.3'ünün gelirinin gidere eşit, \%71.5'inin çalışmadığı belirlenmiştir. Kadınların menstrual siklus ile ilgili özelliklerini incelediğimizde; ilk menstruasyon yaşı ortalamasının $12.8 \pm 1.4$, menstruasyon siklus aralığının $28.9 \pm 5.8$, mentruasyon süresinin $5.7 \pm 1.6$ bulunmuştur (Tablo 1).

Tablo 1. Kadınların Kişisel ve Menstrual Siklus ile İlgili Özellikleri $(\mathrm{n}=406)$

\begin{tabular}{|c|c|c|}
\hline & \multicolumn{2}{|c|}{ Ort \pm SS } \\
\hline Yaş & \multicolumn{2}{|c|}{$26.1 \pm 8.2$} \\
\hline Menarş yaşı & \multicolumn{2}{|c|}{$12.8 \pm 1.4$} \\
\hline $\begin{array}{l}\text { Menstruasyon } \\
\text { aralığ } 1\end{array}$ & \multicolumn{2}{|c|}{$28.9 \pm 5.8$} \\
\hline \multirow[t]{2}{*}{ Mentruasyon süresi } & \multicolumn{2}{|c|}{$5.7 \pm 1.6$} \\
\hline & $\mathbf{n}$ & $\%$ \\
\hline \multicolumn{3}{|l|}{ Medeni Durum } \\
\hline Evli & 119 & 29.3 \\
\hline Bekar & 287 & 70.7 \\
\hline \multicolumn{3}{|l|}{ Aile Tipi } \\
\hline Çekirdek & 350 & 86.2 \\
\hline Geniş & 56 & 13.8 \\
\hline \multicolumn{3}{|l|}{ Eğitim Durumu } \\
\hline Okur-yazar değil & 6 & 1.5 \\
\hline $\begin{array}{l}\text { Okur-yazar ve/veya } \\
\text { ilköğretim }\end{array}$ & 55 & 13.5 \\
\hline Lise ve üzeri & 345 & 85.0 \\
\hline \multicolumn{3}{|l|}{ Gelir Durumu } \\
\hline Gelir giderden az & 65 & 16.0 \\
\hline Gelir gidere eşit & 314 & 77.3 \\
\hline Gelir giderden fazla & 27 & 6.7 \\
\hline \multicolumn{3}{|l|}{ Çalışma Durumu } \\
\hline Çalışmıyor & 290 & 71.5 \\
\hline Çalışıyor & 116 & 28.5 \\
\hline
\end{tabular}

Ort: Ortalama; SS: Standart Sapma; n: Katılımcl sayısi; \%: Yüzde

Kadınların primer dismenoreye ilişkin özelliklerine baktığımızda; \%85.5'inin primer dismenore ağrısı yaşadığı saptanmıştır. Ağrı ile baş etmede kadınların \%41.4'ünün tıbbi tedaviye başvurduğu, \%58.6'sının TAT yöntemlerini kullandığı belirlenmiştir. Kadınların \%69'unun da tıbbi tedaviye ek olarak TAT yöntemlerini kullandığ1 bulunmuştur. TAT yöntemi kullanımı hakkında en fazla bilgi alınan yerin \%16.5 oranı ile internet olduğu ve TAT yöntemleri hakkında en fazla bilgiyi \%41.3 oranı ile hemşireden almak istediği belirlenmiştir. Kadınların \%61.1'inin TAT yöntemlerinin faydalı olduğunu düşündüğü bulunmuştur (Tablo 2).

Çalışmada kadınların "menstruasyonun ilk günleri ve adet döneminde" yaşadıkları primer dismenore ağrısını azaltmak ve rahatlamak için \%57.9'unun yüzüstü ve cenin pozisyonunda uzanma, \%57.6'sının sıcak duş alma, \%57.6'sının uyuma, \%55.5'inin ayaklarına 1s1 uygulama, \%52.2'sinin karına 1s1 uygulama, \%50.2'sinin karına masaj yapma, \%39.9'unun yürüyüş/egzersiz yapma, \%38.7'sinin müzik dinleme, $\% 31.5$ 'inin dua etme, \%25.9'unun nefes egzersizi yapma, \%15.8'inin akupressure yaptırma ya da yapma, \%7.6'sının pilates, \%6.4'ünün yoga ve \%5.7'sinin meditasyon yapma, \%3.2'sinin refleksoloji yaptırma ya da yapma tamamlayıc1 tedavi yöntemlerini uyguladıkları belirlenmiştir (Tablo 3).

Tablo 2. Kadınların Primer Dismenoreye İlişkin Özellikleri ( $\mathrm{n}=406$

\begin{tabular}{|c|c|c|}
\hline & $\mathbf{n}$ & $\%$ \\
\hline \multicolumn{3}{|l|}{ Primer dismenore ağrısı varlığı } \\
\hline Hayır & 59 & 14.5 \\
\hline Evet & 347 & 85.5 \\
\hline \multicolumn{3}{|l|}{$\begin{array}{l}\text { Primer dismenore tedavisinde tıbbi } \\
\text { tedavi alımı }\end{array}$} \\
\hline Hayır & 238 & 58.6 \\
\hline Evet & 168 & 41.4 \\
\hline \multicolumn{3}{|l|}{$\begin{array}{l}\text { Primer dismenore ağrısı ile baş etmede } \\
\text { TAT yöntemi kullanımı }\end{array}$} \\
\hline Hayır & 168 & 41.4 \\
\hline Evet & 238 & 58.6 \\
\hline \multicolumn{3}{|l|}{$\begin{array}{l}\text { Primer dismenore tedavisinde tıbbi } \\
\text { tedaviye ek olarak TAT yöntemi } \\
\text { kullanımı }\end{array}$} \\
\hline Hayır & 52 & 31.0 \\
\hline Evet & 116 & 69.0 \\
\hline \multicolumn{3}{|l|}{$\begin{array}{l}\text { TAT yöntemi kullanımı hakkında bilgi } \\
\text { alınan yer }\end{array}$} \\
\hline Hekim & 40 & 9.9 \\
\hline Hemşire & 24 & 5.9 \\
\hline Aktar & 25 & 6.2 \\
\hline Arkadaş & 39 & 9.6 \\
\hline İnternet & 67 & 16.5 \\
\hline Hastalar & 19 & 4.7 \\
\hline Aile & 49 & 12.0 \\
\hline Fikrim yok & 143 & 35.2 \\
\hline
\end{tabular}

TAT yöntemi hakkında kimden bilgi alınmak istendiği

\begin{tabular}{|c|c|c|}
\hline Hemşire & 168 & 41.4 \\
\hline Ebe & 5 & 1.2 \\
\hline Hekim & 147 & 36.2 \\
\hline Fikrim yok & 86 & 21.2 \\
\hline $\begin{array}{c}\text { TAT yönteminin faydalı olduğunu } \\
\text { düşünme durumu }\end{array}$ & & \\
\hline Hayır & 19 & 4.7 \\
\hline Evet & 249 & 61.3 \\
\hline Fikrim yok & 138 & 34.0 \\
\hline
\end{tabular}

n: Katılımcı sayısı; \%: Yüzde

Kadınların "menstruasyonun ilk günleri ve adet döneminde" yaşadıkları primer dismenore ağrısını azaltmak ve rahatlamak için kullandıkları alternatif tedavi yöntemleri (bitkisel/ besinsel) olarak \%35.2'sinin 1hlamur çayı, \%31'inin yeşil çay, \%30'unun papatya çayı, \%27.3'ünün sicak süt, \%22.4'ünün siyah çay, \% 18.2'sinin tarçın, \%14'ünün rezene çayı ve \%13.5'inin kiraz sapı çayını en fazla kullandığı bulunmuştur (Tablo 4). 
Tablo 3. Primer Dismenore Ağrısı ile Baş Etmede Kullanılan Tamamlayıcı Tedavi Yöntemleri $(n=406)$

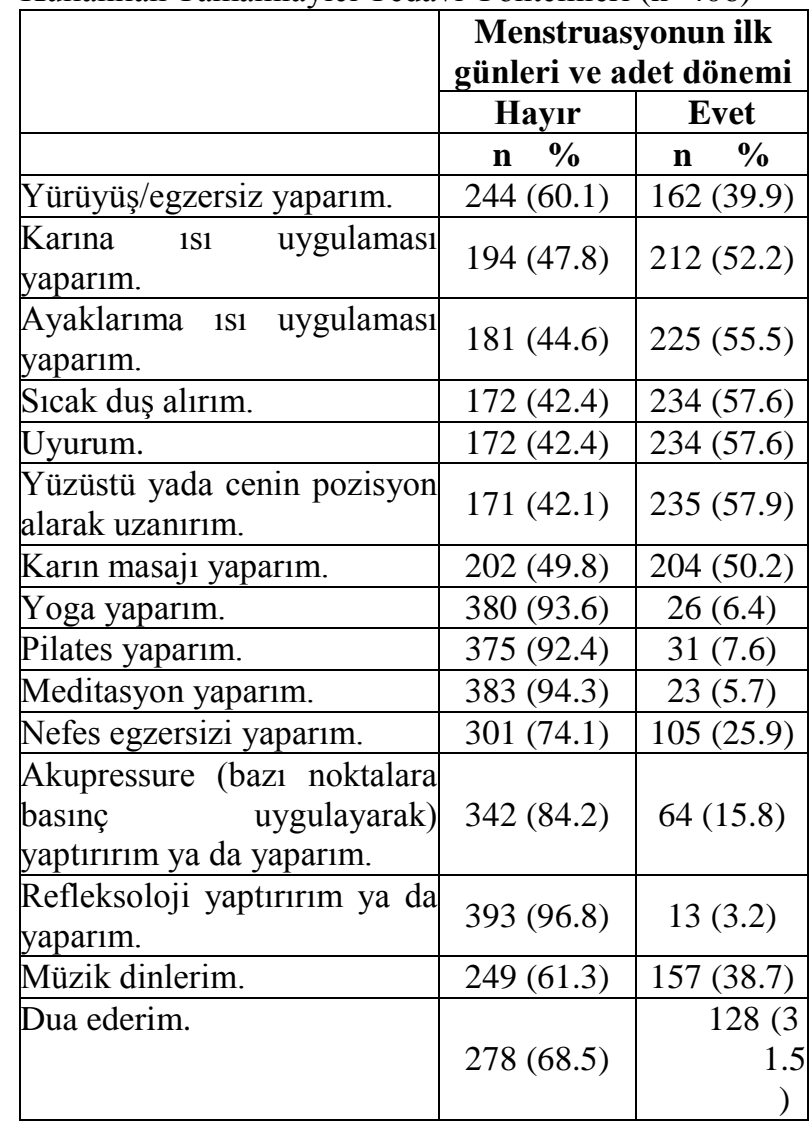

\section{Tartışma}

Primer dismenore dünya genelinde genç kadınların büyük çoğunluğunu etkileyen jinekolojik şikayetlerden biridir. Kadınlar primer dismenore ağrısı ile baş edebilmek için hızlı, güvenilir ve etkili tedavi yaklaşımlarına ihtiyaç duymaktadır. Bu nedenle, primer dismenore ağrısı ile baş etmede tamamlayıcı ve alternatif tedavi (TAT) yöntemleri kullanımına sıklıkla başvurulmaktadır.

Çalışmada kadınların yaş ortalaması $26.1 \pm 8.2$ olarak bulunmuş olup genç kadınların \%85.5'inin primer dismenore ağrısı yaşadığı belirlenmiştir (Tablo 1). Dismenore prevelansına yönelik ülkemizde yapılan çalışmaları incelediğimizde; Keskin ve ark. üniversite öğrencilerinin \%94.5'inde, Elkin \%70.1'inde, Polat ve ark. \%87.8'inde dismenore belirlemiştir [12-14]. Uluslararası çalışmaların prevelans sonuçlarına baktığımızda; Shehata ve ark. Misır'da \%92.9, Omidvar ve ark. Hindistan'da \% 70.2, Habibi ve ark. İran'da \% 89.1, Kamel ve ark. Kahire'de \%88.0, Ferna'ndezMartı'nez ve ark. İspanya'da \%74.8, Farotimi ve ark. Nijerya'da \%78.1, Ortiz Meksika'da \%64, Pejc 'ic' ve Jankovic' ise Sirbistan'da prevelansın \%51 ve \%92.5 arasında değiştiğini bildirmiştir [6, 15-21]. Schoep ve ark. 42.879 kadın örneklemine sahip anket çalışmasında, kadınların \%85'inin dismenore problemi yaşadığ1 saptanmıştır [22]. Ulusal ve uluslararası literatür sonuçları primer dismenorenin özellikle yirmili yaşlardaki genç kadınları etkileyen bir jinekolojik problem olduğunu ve görülme prevelansının da oldukça yüksek olduğunu göstermektedir. Çalışmamıza katılan kadınların yaş ortalamasının genç ve primer dismenore ağrı prevelansının yüksek olmasının literatür sonuçlarını desteklediği görülmektedir.

Tablo 4. Primer Dismenore Ağrısı ile Başetmede Kullanılan Alternatif (Bitkisel/ Besinsel) Tedavi Yöntemleri $(\mathrm{n}=406)$

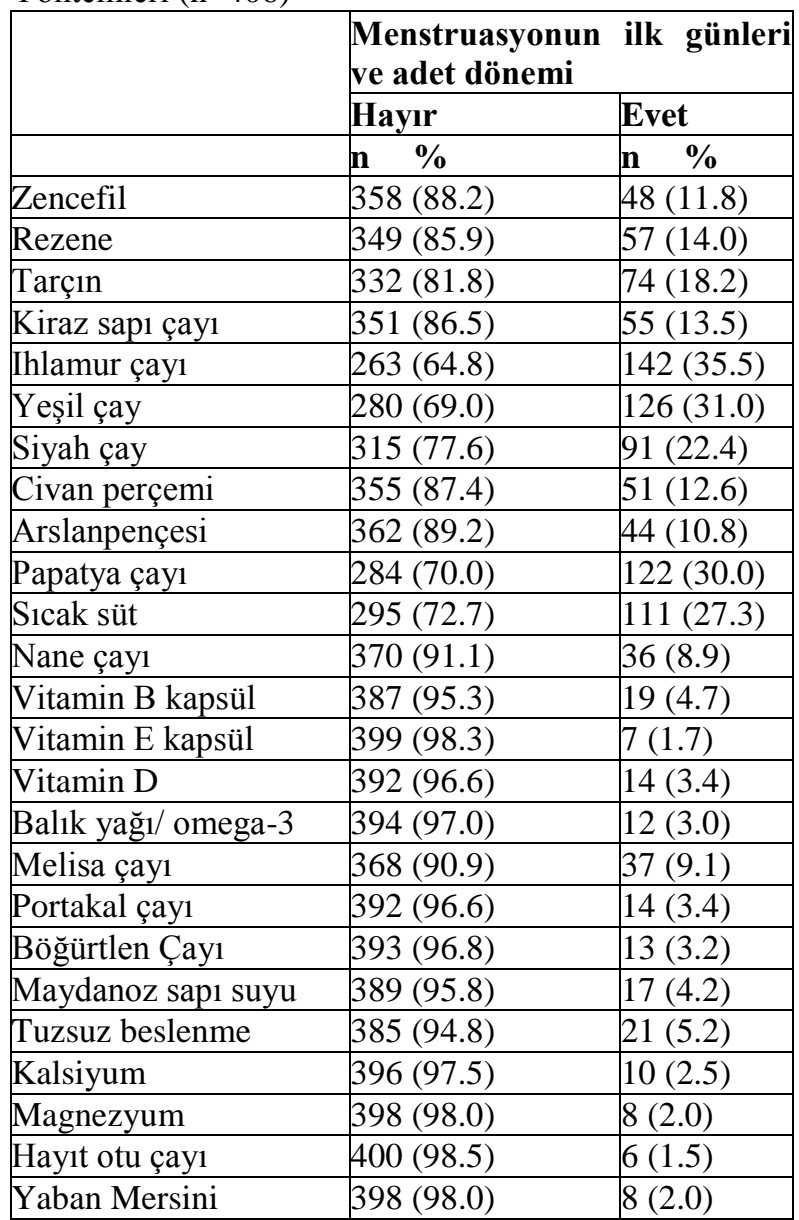

n: Katılımcı sayısı; \%: Yüzde

Çalışmada primer dismenore ağrısı ile baş etmek için kadınların \%58.6'sının TAT yöntemlerini kullandığ1, $\% 69$ 'unun ise tıbbi tedaviye ek olarak TAT yöntemlerini kullandığ $\breve{1}_{\text {ve } \% 61.1 \text { 'inin }}$ TAT yöntemlerinin faydalı olduğunu düşündüğü saptanmıştır (Tablo 2). Primer dismenore ağrısı ile baş etmede TAT yöntemleri kullanımına ilişkin literatür incelendiğinde; Gun ve ark. çalışmalarında, primer dismenore şikayeti olan 18 yaş üzeri üniversite öğrencilerinin \%80.9'unun herhangi bir TAT yöntemine başvurduğunu belirlemiştir [8]. Demirci çalışmasında, kadınların \%78.8'inin dismenore ile baş etmek için daha çok TAT yöntemini tercih ettiğini ve dismenore semptomları 24 saat devam eden ve dismenore ile baş etmede ilaç kullanmayan kadınlarda TAT kullanımının fazla olduğunu, \%46.4'ünün TAT yönteminin faydalı olduğuna inandığını saptamıștır [11]. Keskin ve ark. çalışmalarında, öğrencilerin \%90.1'inin dismenorede TAT yöntemi kullandığını, \%40'ının semptomlar ile baş etmede tıbbi tedaviye ek olarak TAT yöntemi 
kullandığını ve TAT kullanan öğrencilerin \%82.9'unun kullandığı yöntemden fayda gördüğünü düşündüğünü belirlemiştir [12]. Midilli ve ark. çalışmasında, dismenore ağrısı ile baş etmede üniversite öğrencilerinin \%55.1'inin analjezik ilaç ve \%72.2'sinin TAT kullandığını saptamıştır [23]. Elkin çalışmasında, öğrencilerin \%33.6'sının dismenore nedeniyle sağlık kurumuna başvurduğunu bulmuştur [13]. Primer dismenore ağrısı ile baş etmek için genç kadınların TAT yöntemlerine başvurma oranının oldukça yüksek olduğu literatür sonuçlarından görülmektedir. Benzer şeklide çalışmamızda da benzer sonuçlara ulaşılmıştır. Ayrıca genç kadınlar tıbbi tedaviye destek amaçlı TAT yöntemlerine de başvurmaktadırlar.

Çalışmada "menstruasyonun ilk günleri ve adet döneminde" yaşadıkları primer dismenore ağrısını azaltmak ve rahatlamak için kadınların \%57.9'unun yüzüstü ve cenin pozisyonunda uzanma, \%57.6'sının sıcak duş alma, \%57.6'sının uyuma, \%55.5'inin ayaklarına 1S1 uygulama, \%52.2'sinin karına 1S1 uygulama, \%50.2'sinin karına masaj yapma, \%39.9'unun yürüyüş/egzersiz yapma, \%38.7'sinin müzik dinleme, \%31.5'inin dua etme, \%25.9'unun nefes egzersizi yapma, \%15.8'inin akupressure yaptırma ya da yapma, \%7.6'sinın pilates, \%6.4'ünün yoga ve $\% 5.7$ 'sinin meditasyon yapma, \%3.2'sinin refleksoloji yaptırma ya da yapma tamamlayıcı tedavi yöntemlerini uyguladıkları belirlenmiştir (Tablo 3). Demirci çalışmasında, kadınların tamamlayıcı yöntemlerden en çok masaj (\%63.6) ve karına sıcak uygulama (\%52.8) yaptıklarını belirtmiştir [11]. Keskin ve ark. üniversite öğrencilerinde dismenore semptomları ile baş etmek için kullanılan tamamlayıcı yöntemlerin sırasıyla; masaj (\%76.8), sicak su torbası (\%75.1), fiziksel egzersiz (\%69.6), refleksoloji (\%19.9), kayropraksi (\%15.5), meditasyon / yoga (\%11.0), türbe ziyareti/dua etme (\%6.6), akupunktur (\%2.8) ve hipnoz (\%1.7) olduğunu bildirmiştir [12]. Gun ve ark. çalışmalarında, genç kadınların tamamlayıcı yaklaşım olarak \%67.1'inin karına 1s1 uygulama, \%42.6'sinın masaj, \%14.9'unun müzik dinleme, \%14.6'sının egzersiz ve \%13.6'sının gevşeme yöntemlerini kullandığını belirlemiştir [8]. Sut ve Sut yaptığı meta-analiz çalışmasında, uçucu yağlarla yapılan karın masajının primer dismenore ağrısını hafiflettiği saptanmıştır [24]. Midilli ve ark. çalışmalarında, dismenore ağrısı ile baş etmede öğrencilerin \%85.7'sinin sicak uygulama, \%79.2'sinin banyo yapma, \%59.6'sinın masaj, \%37.9'unun spor ve egzersiz, \%32.5'inin rahatlama teknikleri, \%31.3'ünün müzik dinleme tamamlayıcı yöntemlerini kullandığını belirlemiştir [13]. Kamel ve ark. üniversite öğrencilerinin \%50.0'ının dinlenme, \%34.1'inin sicak uygulama, \% 15.0'ının masaj, \%14.2'sinin egzersiz tamamlayıcı tedavi yöntemlerini kullandığını belirlemişlerdir [18]. Houston ve ark. dismenoresi olan kadınların \%58.0'ının dinlendiğini, \%26.0'ının 1sı pedleri kullandığını, \%15.0'ının egzersiz yaptığını belirlemiştir [25]. Graz ve ark. dismenore yaşayan kadınların \%35'inin sicak su torbası yada sicak ped kullandığını belirtmişlerdir [26]. Primer dismenore ağrısı ile baş etmek için genç kadınların tamamlayıcı tedavi yöntemleri olarak karına 1sı uygulama, karına masaj ve egzersiz yöntemlerini çoğunlukla tercih ettikleri görülmektedir. Kadınların tamamlayıcı tedavi yöntemlerine başvurma nedeninin ağrıyı azaltma ve rahatlamada daha hızlı sonuç alınması olduğu düşünülmektedir.

Çalışmada primer dismenore ağrısını azaltmak ve rahatlamak için alternatif tedavi yöntemleri (bitkisel/ besinsel) olarak kadınların \%35.2'sinin ıhlamur çayı, \%31'inin yeşil çay, \%30'unun papatya çayı, $\% 27.3$ 'ünün sicak süt, \%22.4'ünün siyah çay, \% 18.2'sinin tarçın, \%14'ünün rezene çayı ve \%13.5'inin kiraz sapı çayı kullanımını en çok tercih ettiği bulunmuştur (Tablo 4). Keskin ve ark. çalışmalarında, üniversite öğrencilerinin dismenore ağrısı ile başetmek için en çok bitkisel yöntemleri $(\% 63.0)$ ve sebze ağırlıklı yağsız diyet $(\% 32.0)$ ile vitamin tedavisi (\%27.1) kullandıklarını bildirmişlerdir [12]. Demirci çalışmasında, kadınların alternatif tedavi yöntemlerinden papatya çayını $(\% 42.8)$ en fazla kullandıklarını belirlemiştir [11]. Gun ve ark. çalışmalarında, genç kadınların \% 28.4'ünün bitkisel yöntemleri kullandığını, bitkisel yöntem kullananların $\% 15.1$ 'inin papatya çayı, \%11.8'inin siyah çay, \%11.8'inin adaçayı, \%7.9'unun shlamur, \%6.6'sının maydonoz çayı, \%6.0'ının kuşburnu çayı, \%5.3'ünün civanperçemi çayı, \%5.3'ünün kekik çay1, \%5.3'ünün melisa çayı, \%2.6'sının yeşil çay kullandığını ve $\% 5.7$ 'sinin 1 lık süt içtiğini bulmuşlardır [8]. Kamel ve ark. üniversite öğrencilerinin \%56.6'sının sicak içecekler içerek rahatlamaya çalıştıklarını belirlemişlerdir [18]. Graz ve ark. dismenore ağrısı yaşayan kadınların \%23.0'ının besin takviyesi ve bitkisel tedavi kullandığını belirtmişlerdir [26]. Houston ve ark. dismenoresi olan kadınların \%20.0'ının çay tükettiğini belirlemiştir [25]. Midilli ve ark. çalışmalarında, öğrencilerin \%58.9'unun bitkisel çay, \%48.6'sının beslenme ve \%15.9'unun vitamin takviyesi alternatif tedavi yöntemlerini kullandığını bildirmiştir [23]. Literatür ve çalışmamız sonuçlarına göre alternatif tedavi yöntemleri (bitkisel/ besinsel) olarak genç kadınlar, bitkisel çay ve sıcak içecekleri daha fazla tercih etmektedir.

\section{Sonuç ve Öneriler}

Genç kadınların büyük çoğunluğu primer dismenore ağrısı yaşamakta ve ağrı ile baş etmek için TAT yöntemlerini sıklıkla kullanmaktadır. Primer dismenore ağrısı ile baş etmek için kadınlar, tamamlayıcı tedavi yöntemi olarak çoğunlukla karına 1sı uygulama, karına masaj ve egzersiz yöntemlerini; alternatif tedavi yöntemi (bitkisel/ besinsel) olarak da, bitkisel çay ve sıcak içecekleri tercih etmektedir.

$\mathrm{Bu}$ sonuçlar doğrultusunda; sağlık profesyonelleri ve hemşireler tarafından genç kadınlara, primer dismenore ağrısı ile baş etmede TAT yöntemleri kullanımı 
hakkında kanıta dayalı bilgilendirme yapılması ve bilinçli kullanım farkındalığını kazandırılması için eğitim verilmesi önerilmektedir.

\section{Kaynaklar}

1. Hossain G, Sabiruzzaman, Islam S, Hisyam Rz, Lestrel P Kamarul T. Influence of anthropometric measures and sociodemographic factors on menstrual pain and irregular menstrual cycles among university students in Bangladesh. Antrhropological Science. 2011; 119(3): 239-246.

2. Zurawiecka M, Wronka I, Association of primary dysmenorrhea with anthropometrical and socio-economic factors in Polish university students. J Obstet Gynaecol Res. 2018; 44(7): 1259-1267.

3. Tembhurne S, Amritkaur, Mitra M, Relationship between Body Mass Composition and Primary Dysmenorrhoea Indian Journal of Physiotherapy and Occupational Therapy. 2016; 10(1): 76-81.

4. Singh K, Srivastava D, Misra R, Tyagi M. Relationship between Primary Dysmenorrhea and Body Composition Parameters in Young Females. International Journal of Health Sciences and Research. 2015; 5(7): 150-155.

5. Rad M, Sabzevari MT, Rastaghi S, Dehnavi ZM, The relationship between anthropometric index and primary dysmenorehea in female high school students. Journal of Education and Health Promotion. 2018; 7: 34.

6. Pejc 'ic' A, Jankovic' S, Risk factors for dysmenorrhea among young adult female university students. Faculty of Medical Sciences. 2016; 52(1): 98-103.

7. Potur DC, Kömürcü N. Dismenore Yönetiminde Tamamlayıcı Tedaviler. Hemşirelikte Eğitim ve Araștırma Dergisi. 2013;10 (1): 8-13.

8. Gun C, Demirci N, Otrar M. Dismenore yönetiminde tamamlayici alternatif tedavileri kullanma durumu. Spatula DD. 2014; 4(4): 191-197.

9. Uğurluer G, Karahan A, Edirne T, Avni Şahin HA. Ayaktan Kemoterapi Ünitesinde Tedavi Alan Hastaların Tamamlayıcı ve Alternatif Tıp Uygulamalarına Başvurma Sıklığg ve Nedenleri. Van Tip Dergisi. 2007; 14 (3): 68-73.

10. Can G, Erol Ö, Aydiner A, Topuz E. Quality of life and complementary and alternative medicine use among cancer patients in Turkey. Eur J Oncol Nurs. 2009; 13(4): 287-94.

11. Demirci D. Dismenore ile baş etmede kullanılan tamamlayıcı ve alternatif tedavi yöntemleri (Yüksek Lisans Tezi). Aydın: Adnan Menderes Üniversitesi Sağlık Bilimleri Enstitüsü, Kadın Sağlığı ve Hastalıkları Hemşireliği Anabilim Dalı Yüksek Lisans Tezi; 2017.

12. Keskin TU, Yeşilfidan D, Adana F, Okyay P. Aydın Sağlık Yüksekokulu öğrencilerinde perimenstrüel şikâyetler ve başa çıkma yöntemleri. TAF Prev Med Bull. 2016; 15(5): 382388 .

13. Elkin N. Sağlık Bilimleri Yüksekokulu öğrencilerinde premenstrual sendrom görülme sıklığı. Adıyaman Üniv Sağlık Bilim Derg. 2015; 1(2): 94-110.

14. Polat A, Celik H, Gurates B, Kaya D, Nalbant M, Kavak E, et al., Prevalence of primary dysmenorrhea in young adult female university students, Arch Gynecol Obstet. 2009; 279(4): 527-532.

15. Shehata NAA, Arafa AE, El Wahed HAA, Fahim AS Hussein GK. Epidemiology of Dysmenorrhea among University Students in Egypt. Int J Womens Health Wellness. 2018; 4(1): 073.

16. Omidvar S, Bakouei F, Amiri FN, Begum K. Primary dysmenorrhea and menstrual symptoms in Indian female students: Prevalence, impact and management. Glob J Health Sci. 2016; 8(8): 135-144.

17. Habibi N, Huang MS, Gan WY, Zulida R, Safavi SM Prevalence of primary dysmenorrhea and factors associated with its intensity among undergraduate students: a crosssectional study. Pain Manag Nurs. 2015; 16(6): 855-861.

18. Kamel DM, Tantawy SA, Abdelsamea GA. Experience of dysmenorrhea among a group of physical therapy students from Cairo University: an exploratory study. Journal of Pain Research. 2017; 10: 1079-1085.
19. Ferna'ndez-Martı'nez E, Onieva-Zafra MD, ParraFerna'ndez ML. Lifestyle and prevalence of dysmenorrhea among Spanish female university students. PLoS ONE. 2018; 13(8): https://doi.org/10.1371/journal.pone.0201894

$\mathrm{e} 0201894$.

20. Farotimi AA, Esike J, Nwozichi CU, Ojediran TD, Ojewole FO. Knowledge, attitude, and healthcare-seeking behavior towards dysmenorrhea among female students of a private university in Ogun State, Nigeria. Journal of Basic and Clinical Reproductive Sciences. 2015; 4(1): 33-38.

21. Ortiz MI. Primary dysmenorrhea among Mexican university students: prevalence, impact and treatment. Eur J Obstet Gynecol Reprod Biol. 2010; 152(1): 73-77.

22. Schoep ME, Nieboer TE, van der Zanden M, Braat DDM, Nap AW, The impact of menstrual symptoms on everyday life: a survey among 42,879 women, American Journal of Obstetrics and Gynecology. 2019; 1.e1-1.e7. https://doi.org/10.1016/j.ajog.2019.02.048.

23. Midilli TS, Yasar E, Baysal E. Dysmenorrhea characteristics of female students of health school and affecting factors and their knowledge and use of complementary and alternative medicine methods. Holistic Nursing Practice. 2015; 29(4): 194-204.

24. Sut N, Sut HK. Effect of aromatherapy massage on pain in primary dysmenorrhea: A meta-analysis. Complementary Therapies in Clinical Practice. 2017; 27: 5-10.

25. Houston AM, Abraham A, Huang Z, D'Angelo LJ. Knowledge, attitudes, and consequences of menstrual heal thin urban adolescent females. J Pediatr Adolesc Gynecol. 2006; 19: 271-275

26. Graz B, Savoy M, Buclin T, Bonvin E. Dysmenorrhea: patience, pills or hot-water bottle? Rev Med Suisse. 2014; 10 : 2285-2288

http://edergi.cbu.edu.tr/ojs/index.php/cbusbed isimli yazarın CBU-SBED başlıklı eseri bu Creative Commons Alint1-Gayriticari4.0 Uluslararası Lisansı ile lisanslanmıştır. 